\title{
Berat badan lahir rendah (BBLR) dengan kejadian stunting pada anak usia 6-24 bulan
}

Low birth weight to the incidence of stunting in children aged 6-24 months

Darwin Nasution ${ }^{1}$, Detty Siti Nurdiati ${ }^{2}$, Emy Huriyati ${ }^{3}$

\begin{abstract}
Background: Stunting is one of the main problems of malnutrition often found in under-five children. The impacts include delay in child's growth, low endurance, lack of intelligence and productivity. The direct factors that influence the incidence of stunting are low birth weight $(\mathrm{LBW})$ while the indirect factors are socioeconomic factors such as maternal education, low family income and large number of family members. Objective: To analyze the relationship between LBW and the incidence of stunting in children aged 6-24 months in Yogyakarta Municipality. Method: This was a case-control study. The subjects were children aged 6-24 months with a group of cases comprising stunted children based on the indicator of height/age with a cut-off $<-2$ SD Z-score and the control group comprising normal children. The number of subjects for the study was 242 with the under-five children's mothers as the research respondents. The sample selection used non-probability sampling with a consecutive sampling method. The data were analyzed by Chi-Square and multiple logistic regression. Results: The proportion of children 6-24 months who had low birth weight was $15.7 \%$. There was a significant relationship between $L B W$ and the incidence of stunting in children aged 6-24 months (OR=5.60; 95\%CI:2.27 to 15.70). There was a relationship between maternal height and the incidence of stunting in children aged 6-24 months (OR=2.14; 95\%CI:1.08 to 4.33). Socioeconomic factors (maternal education, family income and number of family members) did not have a significant relationship with the incidence of stunting. Conclusion: $L B W$ had a relationship with the incidence of stunting in children aged 6-24 months in Yogyakarta Municipality.
\end{abstract}

KEY WORDS: stunting, low birth weight, children aged 6-24 months

\begin{abstract}
ABSTRAK
Latar belakang: Stunting merupakan salah satu permasalahan kekurangan gizi utama yang sering ditemukan pada anak balita. Dampak yang ditimbulkan antara lain lambatnya pertumbuhan anak, daya tahan tubuh yang rendah, kurangnya kecerdasan, dan produktivitas yang rendah. Salah satu faktor yang mempengaruhi kejadian stunting secara langsung adalah berat badan lahir rendah (BBLR) sedangkan faktor tidak langsung yaitu faktor sosial ekonomi seperti pendidikan ibu dan pendapatan keluarga yang rendah serta jumlah anggota keluarga yang besar. Tujuan: Menganalisis hubungan antara BBLR dengan kejadian stunting pada anak usia 6-24 bulan di Kota Yogyakarta. Metode: Penelitian case control dengan subjek penelitian adalah anak usia 6-24 bulan dengan kelompok kasus adalah anak stunting ( $\mathrm{PB} / \mathrm{U}<-2 \mathrm{SD} Z$-score) dan kelompok kontrol adalah anak yang normal berdasarkan indikator PB/U. Jumlah subjek penelitian untuk kelompok kasus dan kontrol sebanyak 242 dengan ibu balita sebagai responden penelitian. Pemilihan sampel menggunakan teknik non-probability sampling dengan metode consecutive sampling. Analisis data menggunakan uji Chi-Square dan regresi logistik ganda. Hasil: Proporsi anak 6-24 bulan yang mengalami BBLR sebesar 15,7\%. Ada hubungan bermakna antara BBLR dengan kejadian stunting pada anak usia 6-24 bulan (OR=5,60; 95\% $\mathrm{CI}: 2,27-15,70)$. Ada hubungan antara tinggi badan ibu dengan kejadian stunting pada anak usia 6-24 bulan (OR=2,14; 95\%CI:1,08-4,33). Faktor sosial ekonomi (pendidikan ibu, pendapatan keluarga, dan jumlah anggota keluarga) tidak memiliki hubungan bermakna dengan kejadian stunting. Simpulan: BBLR berhubungan dengan kejadian stunting pada anak usia 6-24 bulan di Kota Yogyakarta.
\end{abstract}

KATA KUNCI: stunting, BBLR, anak usia 6-24 bulan

\section{PENDAHULUAN}

Permasalahan gizi, khususnya stunting pada anak merupakan salah satu keadaan kekurangan gizi yang

\footnotetext{
Korespondensi: Dinas Kesehatan Provinsi Sumatera Utara, Jl. Kapt. Sumarsono No. 1 Medan, Sumatera Utara

2 Departemen Obstetri dan Ginekologi, Fakultas Kedokteran Universitas Gadjah Mada, Jl. Farmako, Sekip Utara, Yogyakarta 55281

3 Program Studi Gizi Kesehatan, Fakultas Kedokteran Universitas Gadjah Mada, Jl. Farmako, Sekip Utara, Yogyakarta 55281
}

menjadi perhatian utama di dunia terutama di negaranegara berkembang, memberikan dampak lambatnya pertumbuhan anak, daya tahan tubuh yang rendah, kurangnya kecerdasan, dan produktivitas yang rendah (1). Prevalensi stunting di dunia sebesar 26,9\% dan di negaranegara berkembang di Asia sebesar 31,3\% (2) sedangkan di Indonesia lebih tinggi lagi yaitu $35,6 \%$ dan pada kelompok usia 6-23 bulan adalah yang tertinggi (3). 
Salah satu faktor risiko yang mempengaruhi kejadian stunting pada anak balita adalah riwayat berat badan lahir rendah (BBLR) (4). Akibatnya pertumbuhan bayi BBLR akan terganggu, bila keadaan ini berlanjut dengan pemberian makanan yang tidak mencukupi, sering mengalami infeksi, dan perawatan kesehatan yang tidak baik dapat menyebabkan anak stunting. Namun, secara tidak langsung kejadian stunting juga dipengaruhi oleh faktor sosial ekonomi, seperti tingkat pendidikan, pendapatan, dan jumlah anggota rumah tangga (5).

Berdasarkan data dari Dinas Kesehatan Kota Yogyakarta tahun 2012, ditemukan prevalensi stunting sebesar $15,92 \%$ pada anak balita. Prevalensi BBLR dari tahun 2007 sampai dengan tahun 2010 juga cenderung meningkat, yaitu prevalensi tahun 2007 sebesar $0,98 \%$ meningkat menjadi 5,51\% pada tahun 2010 (6). Melihat kondisi ini apakah ada hubungan antara BBLR dengan kejadian stunting di Kota Yogyakarta sebagai salah satu faktor risiko, yang akan berdampak buruk bagi generasi penerus karena tingginya prevalensi stunting mengindikasikan tingkat intelegensia dan produktivitas masyarakat yang rendah (7). Tujuan penelitian ini adalah untuk menganalisis hubungan antara BBLR dengan kejadian stunting pada anak usia 6-24 bulan di Kota Yogyakarta.

\section{BAHAN DAN METODE}

Penelitian ini adalah nested research dari penelitian yang berjudul faktor-faktor yang berhubungan dengan kejadian stunting pada anak usia 6-24 bulan di Kota Yogyakarta. Jenis penelitian analitik observasional dengan rancangan kasus kontrol (case control study) menggunakan metode kuantitatif. Lokasi penelitian di tiga kecamatan dari 14 kecamatan yang ada di Kota Yogyakarta Provinsi Daerah Istimewa Yogyakarta yaitu Tegalrejo, Umbulharjo, dan Kotagede. Waktu penelitian selama 4 bulan yaitu pada bulan Maret sampai dengan Juni 2013.

Populasi dan subjek penelitian ini adalah semua anak usia 6-24 bulan di Kota Yogyakarta yang tercatat di posyandu pada 3 wilayah kecamatan terpilih serta orangtuanya bertempat tinggal di lokasi penelitian, serta memenuhi kriteria inklusi dan eksklusi. Kriteria inklusi kasus yaitu anak mengalami stunting; anak kandung responden; jika pada keluarga terdapat lebih dari satu anak maka anak paling muda yang dijadikan sebagai sampel; dan ibu subjek bersedia menjadi responden penelitian. Kriteria eksklusi yaitu anak yang mengalami kelainan kongenital atau cacat fisik. Sementara itu, kriteria inklusi kontrol yaitu anak tidak stunting; anak kandung responden; jika keluarga memiliki lebih dari satu anak, maka anak yang paling muda yang dijadikan sebagai sampel; dan ibu bersedia menjadi responden penelitian sedangkan kriteria eksklusi adalah anak yang mengalami kelainan kongenital atau cacat fisik.

Berdasarkan perhitungan besar sampel menggunakan rumus matched case control studies (8) dengan derajat kepercayaan $95 \%$; kekuatan uji $80 \%$; dan $\mathrm{OR}=3,2$ (9) diperoleh sampel minimal sebesar 79 anak untuk masing-masing kelompok sehingga total besar sampel untuk kedua kelompok adalah 158 responden. Penelitian ini merupakan penelitian nested research sehingga peneliti memutuskan menggunakan besar sampel dari hasil perhitungan variabel terbesar yaitu variabel ASI eksklusif sebagai faktor risiko stunting. Besar sampel variabel ASI eksklusif kelompok kasus 121 anak dan kelompok kontrol 121 anak sehingga total besar sampel untuk kedua kelompok sebesar 242 anak. Pemilihan sampel penelitian menggunakan teknik non-probability sampling dengan metode consecutive sampling. Pengambilan sampel dilakukan secara berurutan di 14 kelurahan di tiga wilayah kecamatan, kegiatan pengambilan sampel dihentikan setelah jumlah sampel yang diperlukan terpenuhi.

Variabel penelitian ini terdiri dari variabel terikat yaitu anak stunting usia 6-24 bulan, variabel bebas adalah riwayat BBLR, dan variabel luar adalah pendidikan ibu, pendapatan keluarga, jumlah anggota keluarga, dan tinggi badan ibu. Stunting adalah anak usia 6-24 bulan yang tergolong pendek berdasarkan indikator panjang badan menurut umur (PB/U) dengan nilai Z-score kurang dari -2 SD (10). Berat badan lahir rendah (BBLR) adalah berat badan anak usia 6-24 bulan pada saat dilahirkan, dikategorikan menjadi dua yaitu BBLR jika berat lahir kurang dari $2.500 \mathrm{~g}$ dan normal apabila berat badan lahir lebih dari atau sama dengan $2.500 \mathrm{~g}$ (11) yang diperoleh dari catatan kelahiran anak pada buku kesehatan ibu dan anak (KIA) dan kartu menuju 
sehat (KMS). Pendidikan ibu adalah tingkat pendidikan formal ibu yang dikategorikan rendah (tidak sekolah, tidak tamat SD, tamat SD, tamat SMP) dan tinggi (tamat SMA atau tamat perguruan tinggi). Penghasilan keluarga adalah besarnya pendapatan keluarga (bapak, ibu, anggota keluarga lain) yang dikelompokkan berdasarkan upah minimum kota (UMK) Yogyakarta tahun 2013 yaitu Rp 1.065.247,-Jumlah anggota keluarga yang hidup dalam satu rumah dan menjadi tanggungan kepala rumah tangga dikelompokkan menjadi dua kategori yaitu keluarga kecil (jumlah anggota keluarga $\leq 4$ orang) dan keluarga besar (jumlah anggota keluarga $>4$ orang). Tinggi badan ibu diukur menggunakan microtoise dengan ketelitian $0,1 \mathrm{~cm}$ dalam keadaan berdiri dan dikategorikan menjadi dua yaitu pendek $(<150 \mathrm{~cm})$ dan normal ( $\geq 150 \mathrm{~cm})(12)$.

Instrumen penelitian meliputi kuesioner terstruktur, alat pengukur panjang badan (lengthboard), alat pengukur tinggi badan (microtoise) untuk mengukur tinggi badan ibu (ketelitian 0,1 cm), tabel baku standar Z-score WHO 2005, buku kesehatan ibu dan anak (KIA), dan kartu menuju sehat (KMS) balita. Pengolahan data menggunakan sofware program stata dan analisis data menggunakan uji Chi-Square dan regresi logistik ganda (13). Penelitian ini telah memperoleh ethical clearance dari Komisi Etik Fakultas Kedokteran Universitas Gadjah Mada dengan nomor KE/FK/250/EC.

\section{HASIL}

\section{Karakteristik responden}

Sebagian besar responden berpendidikan tinggi $(67,8 \%)$, pendapatan keluarga cukup berdasarkan UMR Kota Yogyakarta $(69,42 \%)$, status jumlah anggota keluarga kecil yaitu kurang dari 4 orang $(61,2 \%)$, dan distribusi tinggi badan ibu tergolong normal $(78,9 \%)$. Berat badan lahir subjek penelitian ini sebagian besar tergolong normal $(84,3 \%)$ dan hanya sebagian kecil bayi dengan berat badan lahir rendah $(15,7 \%)$.

Hasil analisis menunjukkan nilai $\mathrm{OR}=5,60(95 \%$ CI: 2,27-15,70), artinya pada tingkat kepercayaan 95\% dapat disimpulkan bahwa anak yang lahir dengan BBLR mempunyai risiko 5,6 kali lebih besar untuk menjadi stunting dibandingkan dengan anak yang lahir dengan berat badan normal. Persentase untuk variabel pendidikan ibu menunjukkan bahwa ibu yang berpendidikan lebih tinggi memiliki anak stunting lebih banyak dibandingkan ibu yang berpendidikan rendah $(68,6 \%$ vs $31,4 \%)$. Sementara itu, keluarga dengan pendapatan cukup memiliki anak stunting lebih banyak dibandingkan keluarga yang berpendapatan rendah $(66,94 \%$ vs 3,06 \%) (Tabel 1).

Lebih lanjut, Tabel 1 menunjukkan bahwa jumlah anggota keluarga yang besar dan memiliki anak stunting sebanyak 63,6\% sedangkan jumlah anggota keluarga

Tabel 1. Hubungan berat badan lahir dan variabel luar dengan kejadian stunting

\begin{tabular}{|c|c|c|c|c|c|}
\hline \multirow{2}{*}{ Variabel } & \multicolumn{2}{|c|}{ Kasus } & \multicolumn{2}{|c|}{ Kontrol } & \multirow{2}{*}{$\begin{array}{c}\text { OR } \\
(95 \% \mathrm{CI})\end{array}$} \\
\hline & n & $\%$ & $\mathbf{n}$ & $\%$ & \\
\hline \multicolumn{6}{|l|}{ Berat badan lahir } \\
\hline BBLR & 31 & 25,6 & 7 & 5,8 & $5,60 *$ \\
\hline Normal & 90 & 74,4 & 114 & 94,2 & $(2,27-15,70)$ \\
\hline \multicolumn{6}{|l|}{ Pendidikan ibu } \\
\hline Rendah & 38 & 31,4 & 40 & 33,1 & 0,92 \\
\hline Tinggi & 83 & 68,6 & 81 & 66,9 & $(0,52-1,64)$ \\
\hline \multicolumn{6}{|c|}{ Pendapatan keluarga } \\
\hline Kurang & 40 & 33,06 & 34 & 28,10 & 1,26 \\
\hline Cukup & 81 & 66,94 & 87 & 71,90 & $(0,73-2,18)$ \\
\hline \multicolumn{6}{|c|}{ Jumlah anggota keluarga } \\
\hline Besar & 77 & 63,6 & 47 & 38,8 & 1,00 \\
\hline Kecil & 44 & 36,4 & 74 & 61,2 & $(0,57-1,73)$ \\
\hline \multicolumn{6}{|l|}{ Tinggi badan ibu } \\
\hline Pendek & 33 & 27,3 & 18 & 14,9 & $2,14^{*}$ \\
\hline Normal & 88 & 72,7 & 103 & 85,1 & $(1,08-4,33)$ \\
\hline
\end{tabular}

Keterangan: *bermakna $(95 \% \mathrm{CI})$ 
kecil yang memiliki anak stunting sebanyak $36,4 \%$. Sementara untuk ibu dengan tinggi badan normal yang memiliki anak balita stunting sebanyak $72,7 \%$ sedangkan ibu dengan tinggi badan yang pendek dan memiliki anak balita stunting sebanyak 27,3\%. Hasil analisis statistik menunjukkan bahwa tinggi badan ibu bermakna dengan stunting jika dilihat dari OR=2,14 (95\% CI:1,08-4,33) dan dapat disimpulkan bahwa anak yang dilahirkan dari ibu yang pendek mempunyai risiko 2,14 kali lebih besar mengalami kejadian stunting dibandingkan anak yang dilahirkan dari ibu dengan tinggi badan normal. Variabel luar yaitu pendidikan ibu, pendapatan keluarga, dan jumlah anggota keluarga, tidak menunjukkan hubungan bermakna dengan kejadian stunting.

Berdasarkan hasil uji statistik bivariat, variabel yang memiliki nilai kemaknaan adalah berat badan lahir dan tinggi badan ibu. Selanjutnya, kedua variabel penelitian tersebut dianalisis menggunakan analisis regresi untuk menentukan apakah kedua variabel ini secara bersama-sama berpengaruh terhadap kejadian stunting pada anak (Tabel 2).

Hasil analisis model 1 menunjukkan hubungan yang bermakna secara statistik antara berat badan lahir dengan kejadian stunting. Berdasarkan analisis tersebut diperoleh nilai $\mathrm{OR}=5,60$ (95\% CI:2,36-13,32) sehingga dapat disimpulkan bahwa riwayat BBLR berpeluang 5,60 kali lebih besar menjadi stunting dibandingkan dengan anak tidak BBLR (normal). Model 1 menghasilkan nilai $\mathrm{R}^{2}=0,06$ yang artinya riwayat BBLR berkontribusi terhadap kejadian stunting sebesar 6\% sedangkan $94 \%$ dipengaruhi faktor lain. Sementara itu, model 2 menunjukkan nilai OR mengalami perubahan yang semula 5,60 (95\% CI:2,36-13,32) menjadi 5,67 (95\% CI:2,37-13,57). Hal ini dapat diinterpretasikan bahwa riwayat BBLR jika dipengaruhi variabel tinggi badan ibu berpeluang 5,67 kali lebih besar menjadi stunting dibandingkan dengan anak normal. Dari hasil model 2 diperoleh nilai $\mathrm{R}^{2}$ sebesar 0,07 yang mengalami peningkatan dibandingkan model 1. Artinya, riwayat BBLR dengan mengontrol variabel tinggi badan ibu dapat memprediksi kejadian stunting sebesar 7\%. Model 2 juga menunjukkan bahwa variabel tinggi badan ibu ketika diuji secara bersamaan dengan BBLR menunjukkan nilai OR meningkat dari $\mathrm{OR}=2,14$ (95\% CI:1,08-4,33) meningkat menjadi OR=2,18 (95\%
Tabel 2. Analisis regresi logistik variabel bebas dan variabel luar terhadap kejadian stunting

\begin{tabular}{lcc}
\hline \multirow{2}{*}{ Variabel } & Model 1 & Model 2 \\
\cline { 2 - 3 } & OR (95\% CI) & OR (95\% CI) \\
\hline Riwayat kelahiran & & \\
$\quad$ BBLR & 5,60 & 5,67 \\
$\quad$ Normal & $(2,36-13,32)$ & $(2,37-13,57)$ \\
Tinggi badan ibu & & \\
$\quad$ Pendek & & 2,18 \\
$\quad$ Normal & & $(1,12-4,23)$ \\
$\mathrm{R}^{2}$ & 0,06 & 0,07 \\
Deviance & 316,28 & 310,75 \\
$\mathrm{~N}$ & 242 & 242 \\
\hline
\end{tabular}

CI:1,12-4,23). Berdasarkan hasil analisis ini dapat diinterpretasikan bahwa BBLR dan tinggi badan ibu menjadi faktor yang meningkatkan risiko kejadian stunting tanpa mempengaruhi kemaknaan satu sama lain.

\section{BAHASAN}

Hasil analisis menunjukkan bahwa terdapat hubungan antara BBLR dengan kejadian stunting pada anak usia 6-24 bulan yaitu 5,6 kali lebih berisiko untuk mengalami kejadian stunting pada anak dengan riwayat BBLR dibandingkan anak yang lahir dengan berat badan normal. Kondisi ini dapat terjadi karena pada bayi yang lahir dengan BBLR, sejak dalam kandungan telah mengalami retardasi pertumbuhan interauterin dan akan berlanjut sampai usia selanjutnya setelah dilahirkan yaitu mengalami pertumbuhan dan perkembangan yang lebih lambat dari bayi yang dilahirkan normal dan sering gagal menyusul tingkat pertumbuhan yang seharusnya dicapai pada usianya setelah lahir (4). Hambatan pertumbuhan yang terjadi berkaitan dengan maturitas otak yaitu sebelum usia kehamilan 20 minggu terjadi hambatan pertumbuhan otak seperti pertumbuhan somatik (14).

Penelitian menemukan bahwa pada bayi BBLR kecil masa kehamilan, setelah berusia 2 bulan mengalami gagal tumbuh (growth falthering) (7). Gagal tumbuh pada usia dini ( 2 bulan) menunjukkan risiko untuk mengalami gagal tumbuh pada periode berikutnya. Usia 12 bulan bayi BBLR kecil masa kehamilan tidak mencapai panjang badan yang dicapai oleh anak normal, meskipun anak normal tidak bertumbuh optimal, dengan kata lain kejar tumbuh (catch up growth) tidak memadai. Kejar tumbuh 
pada anak yang lahir BBLR berlangsung hingga usia dua tahun. Gagal tumbuh dan kejar tumbuh yang tidak memadai merupakan suatu keadaan patologis yang menyebabkan kejadian stunting pada balita (15).

Bayi BBLR juga mengalami gangguan saluran pencernaan karena saluran pencernaan belum berfungsi seperti kurang dapat menyerap lemak dan mencerna protein sehingga mengakibatkan kurangnya cadangan zat gizi dalam tubuh. Akibatnya, pertumbuhan bayi BBLR akan terganggu dan apabila keadaan ini berlanjut dengan pemberian makanan yang tidak mencukupi, sering mengalami infeksi, dan perawatan kesehatan yang tidak baik, dapat menyebabkan anak mengalami stunting. Hasil penelitian ini sejalan dengan penelitian di Vietnam bahwa riwayat BBLR merupakan faktor risiko utama untuk stunting pada anak usia di bawah tiga tahun $(\mathrm{OR}=4,4$; 95\% CI:2,08-9,10) (16).

Tingginya prevalensi BBLR dan stunting pada masa balita di Kota Yogyakarta ini akan berdampak buruk bagi generasi penerus di Kota Yogyakarta karena dengan tingginya prevalensi stunting mengindikasikan tingkat intelegensia dan produktivitas masyarakat yang rendah (7). Prevalensi stunting yang tinggi pada anak balita jika tidak diimbangi dengan perbaikan gizi yang memadai akan berlanjut pada usia selanjutnya yaitu pada masa sekolah. Di Indonesia, ditemukan bahwa anak usia sekolah tergolong pendek ketika memasuki usia sekolah sebesar $36,1 \%$ sebagai indikator adanya kurang gizi kronis (17). Lebih lanjut, anak yang terlahir BBLR jika pada usia sekolah tidak memperoleh perbaikan gizi yang memadai dan pelayanan kesehatan yang baik akan berlanjut pada usia selanjutnya yaitu usia remaja yang pendek. Sebuah penelitian di Cina menemukan bahwa remaja yang lahir dengan berat badan lahir 1200-2499 g akan mengalami ketinggalan dalam pertumbuhan fisik, kapasitas kognitif, dan kemampuan akademik dibandingkan dengan remaja yang lahir dengan berat badan lebih dari $2.500 \mathrm{~g}(16)$.

Hasil penelitian menunjukkan tidak adanya hubungan yang bermakna antara tingkat pendidikan ibu dengan kejadian stunting. Keadaan ini dapat terjadi karena ibu rumah tangga yang berpendidikan tinggi di Kota Yogyakarta sangat dominan yaitu sebesar $67,8 \%$. Tingkat pendidikan formal umumnya mencerminkan kemampuan seseorang untuk memahami berbagai aspek pengetahuan termasuk gizi. Penelitian lain menemukan bahwa pengetahuan gizi secara formal di Indonesia mulai tingkat SD sampai SMU diajarkan sebagai pendidikan gizi yang merupakan bagian dari pelajaran ekonomi rumah tangga sedangkan bagi ibu rumah tangga yang belum mendapatkan pengetahuan gizi melalui pendidikan formal di sekolah bisa mendapatkannya melalui pendidikan nonformal. Di Indonesia, pengetahuan gizi juga diajarkan sebagai bagian dari pendidikan nonformal, terutama yang melibatkan wanita dalam organisasi atau kelompok sosial seperti dalam pemberdayaan dan kesejahteraan keluarga (PKK), pos pelayanan terpadu (Posyandu), dan organsiasi Dharma Wanita (18).

Pendidikan gizi juga bisa diperoleh dari tenaga kesehatan di Puskesmas dan Posyandu yang tersebar di 14 kecamatan di Yogyakarta dan dari media massa seperti majalah, televisi, dan internet sehingga para ibu balita atau pembantunya mudah mendapatkan informasi tentang bagaimana menyiapkan dan menyajikan makanan yang murah dan bergizi bagi keluarga. Hal ini juga sejalan dengan pendapat bahwa kelompok orang yang tinggal di perkotaan atau wilayah dengan berbagai fasilitas penunjang yang lengkap, memiliki pengalaman di bidang gizi lebih baik dibandingkan kelompok di perdesaan dengan alasan kelompok yang tinggal di daerah perkotaan mempunyai akses ke para ahli gizi dan kesehatan yang lebih mudah (18).

Pola yang umum dalam pengambilan keputusan pemilihan pangan di Indonesia adalah pola istri dominan sekaligus berperan mengatur makanan keluarga. Oleh karena itu, pendidikan formal ibu sangat diperlukan untuk meningkatkan pengetahuan dalam upaya mengatur dan mengetahui kebutuhan gizi anggota keluarganya. Pendidikan ibu yang baik memudahkan untuk menerima informasi dari luar terutama pemberian makanan bergizi pada anak sehingga terhindar dari bahaya kurang gizi. Sebaliknya, pada ibu dengan tingkat pendidikan yang rendah, pengetahuan dan kebiasaan mengasuh diperolehnya dari orangtua dan tetangga yang mungkin memiliki taraf pendidikan dan pengalaman kurang, keadaan ini menjadi faktor penghambat dalam melakukan pengasuhan anak yang maksimal dan mengakibatkan kejadian stunting pada anak (18). 
Lebih lanjut, diketahui bahwa lebih dari $2 / 3$ keluarga subjek penelitian mempunyai pendapatan keluarga yang cukup dan hasil penelitian menunjukkan bahwa tingkat pendapatan keluarga merupakan faktor risiko kejadian stunting tetapi secara statistik hubungan ini tidak bermakna. Hal ini dapat disebabkan pendapatan yang diterima tidak sepenuhnya digunakan untuk kebutuhan pokok tetapi untuk kebutuhan lainnya. Tingkat pendapatan yang tinggi belum menjamin status gizi yang baik pada balita karena pendapatan belum tentu teralokasikan cukup untuk keperluan makan. Hal yang sama ditemukan pada hasil penelitian di Meksiko bahwa pendapatan keluarga meningkatkan kejadian stunting pada anak usia 6-23 bulan (19).

Tidak adanya hubungan yang bermakna antara tingkat pendapatan dengan kejadian stunting sesuai dengan pendapat bahwa pertumbuhan bayi tidak terlalu terpengaruh dengan pendapatan karena walaupun pendapatan keluarga tergolong rendah jika mampu mengelola makanan yang bergizi dengan bahan yang sederhana dan murah maka pertumbuhan bayi juga akan menjadi baik (20). Keadaan ini dapat juga disebabkan stunting merupakan gambaran status gizi masa lampau, sementara pendapatan keluarga yang dinilai berdasarkan UMR Kota Yogyakarta tahun 2013 adalah dilakukan pada saat penelitian.

Demikian juga dengan hasil analisis pada jumlah anggota keluarga yang tidak menunjukkan hubungan yang bermakna dengan kejadian stunting pada balita. Hal ini karena sebagian besar rumah tangga memiliki anggota keluarga kecil yaitu kurang dari 4 orang dan pendapatan keluarga di atas UMR Kota Yogyakarta. Hasil ini berbeda dengan penelitian yang dilakukan di Brazil bahwa semakin besar jumlah anggota keluarga yang tinggal dalam satu rumah maka anak akan memiliki kecenderungan mengalami stunting pada usia kurang dari lima tahun (21). Begitu pula dengan penelitian tentang faktor risiko kejadian stunting yang menyatakan bahwa jumlah anggota rumah tangga yang lebih banyak disertai pendapatan keluarga rendah, maka anggota keluarga tersebut terutama anak-anak berpeluang untuk tidak mendapat asupan lebih baik guna memenuhi kebutuhan tubuhnya (22).

Berbeda dengan tinggi badan ibu yang menunjukkan hasil bermakna yaitu tinggi badan ibu yang pendek berisiko 2,14 kali lebih besar menyebabkan kejadian stunting pada anak dibandingkan tinggi badan ibu yang normal. Hasil ini sejalan dengan penelitian tentang tinggi badan ibu sebagai faktor risiko kejadian stunting pada anak (23). Hasil penelitian ini mendukung hasil penelitian sebelumnya yang membuktikan bahwa tinggi badan ibu kurang dari atau sama dengan 150 $\mathrm{cm}$ mempunyai risiko 2,2 kali untuk melahirkan anak stunting (24). Walaupun tinggi badan ibu berhubungan dengan kejadian stunting, variabel ini bukan merupakan faktor utama yang menentukan tinggi badan anak balita, tetapi kendala lingkungan dan gizi menjadi faktor yang jauh lebih penting (25).

Didukung hasil analisis multivariat yaitu riwayat BBLR jika dipengaruhi oleh variabel tinggi badan ibu, berpeluang 5,67 kali lebih besar menjadi stunting dibandingkan anak dengan berat badan lahir normal. Riwayat BBLR dengan mengontrol variabel tinggi badan ibu dapat memprediksi kejadian stunting hanya sebesar $7 \%$ sedangkan $93 \%$ kontribusi faktor risiko lainnya. Dari hasil analisis juga menunjukkan bahwa BBLR dan tinggi badan ibu sama-sama merupakan faktor risiko meningkatnya kejadian stunting pada balita tanpa saling mempengaruhi kemaknaan satu sama lain.

\section{SIMPULAN DAN SARAN}

Berat badan lahir rendah berhubungan dengan kejadian stunting pada anak usia 6-24 bulan di Kota Yogyakarta. Anak dengan riwayat kelahiran BBLR berisiko 5,6 kali lebih besar untuk menjadi stunting dibandingkan anak dengan riwayat kelahiran normal. Kepada para tenaga kesehatan dan stakeholder di Kota Yogyakarta diharapkan turut mensukseskan gerakan 1000 hari pertama kehidupan (gerakan 1000 HPK). Pemenuhan asupan gizi pada 1000 HPK anak sangat penting, dengan mendapatkan asupan gizi yang optimal maka penurunan status gizi anak bisa dicegah lebih awal sehingga anak tidak mengalami BBLR dan dengan cara ini diharapkan kejadian stunting pada anak balita juga ikut menurun.

\section{RUJUKAN}

1. Kurniasih D, Hilmansyah H, Astuti M, Imam S. Sehat \& bugar berkat gizi seimbang. Jakarta: Kompas Gramedia; 2010. 
2. Umeta M, West CE, Verhoef H, Haidar J, Hautvast JG. Factors associated with stunting in infants aged 5-11 months in the Dodota-Sire District, rural Ethiopia. J Nutr 2003;133(4):1064-9.

3. Kemenkes RI. Riset kesehatan dasar (RISKESDAS) 2010. Jakarta: Badan Penelitian dan Pengembangan Kemenkes RI; 2010.

4. Proverawati A, Ismawati C. BBLR (berat badan lahir rendah). Yogyakarta: Nuha Medika; 2010.

5. Soetjiningsih. Tumbuh kembang anak. Jakarta: Buku Kedokteran EGC; 2012.

6. Dinkes Kota Yogyakarta. Profil kesehatan Kota Yogyakarta tahun 2012. Yogyakarta: Dinas Kesehatan Kota Yogyakarta; 2012.

7. Sudirman H. Stunting atau pendek: awal perubahan patologis atau adaptasi karena perubahan sosial ekonomi yang berkepanjangan? Media Penelitian dan Pengembangan Kesehatan 2008;18(1):33-42.

8. Schlesselman JJ, Stolle PD. Case control studies: design, conduct, analysis. New York: Oxford University Press; 1982.

9. Bove I, Miranda M, Campoy C, Uauy R, Napol M. Stunting, overweight and child development impairment go hand in hand as key problems of early infancy: Uruguayan case. Early Human Development 2012;88:747-51.

10. WHO. Child growth standards: length/height-for-age, weight-for-age, weight-for-lenght, weight for height snd body mass index-for-age: methods and develpoment. Geneva: Departement of Nutrition for Helath and Development; 2006.

11. UNICEF \& WHO. Low birthweight. Genewa: United Nation Children's Fund and World Health Organization; 2004.

12. Jahari AB. Median berat badan dan tinggi badan normal orang Indonesia berdasarkan data Riskesdas 2007 dan 2010. Jakarta: Widya Karya Nasional Pangan dan Gizi X - LIPI; 2012.

13. Sastroasmoro S, Ismael S. Dasar-dasar metodologi penelitian klinis. Jakarta: Sagung Seto; 2011.

14. Meadow R, Newell S. Lectures notes pediatrika. Jakarta: Penerbit Erlangga; 2005.
15. Atkinson SA, Simpson JR. Factors influencing body composition of premature infants at term-adjusted age. Ann N Y Acad Sci 2000;904:393-9.

16. Hien NN, Hoa NN. Nutritional status and determinants of malnutrition in children under three years of age in Nghean, Vietnam. Pak J Nutr 2009;8(7):958-64.

17. Fatmawati, Nuryati S. Gizi buruk dan masa depan bangsa. [series online] 2006 [cited 2013 Oktober 13]. Available from: URL: http://www.republika.co.id.html

18. Hardinsyah. Review faktor determinan keragaman konsumsi pangan (review on determinant factors of dietary diversity). Jurnal Gizi dan Pangan 2007;2(2):55-74.

19. Reyes H, Pérez-Cuevas R, Sandoval A, Castillo R, Santos JI, Doubova SV, Gutiérrez G. The family as a determinant of stunting in children living in conditions of extreme poverty: a case-control study. BMC Public Health 2004;4:57.

20. Anindita P. Hubungan tingkat pendidikan ibu, pendapatan keluarga, kecukupan protein \& zinc dengan stunting (pendek) pada balita usia 6-35 bulan di Kecamatan Tembalang Kota Semarang. Jurnal Kesehatan Masyarakat 2012;1(2):617-26.

21. Menezes RCEd, Lira PICd, Leal VS, Oliveira JS, Santana SCdS, Sequeira LAdS, Rissin A, Filho MB. Determinants of stunting in children under five in Pernambuco, Northeastern Brazil. Rev Saúde Pública 2011;45(6):1079-87.

22. Wahdah S, Juffrie M, Huriyati E. Faktor risiko kejadian stunting pada anak umur 6-36 bulan di wilayah pedalaman Kecamatan Silat Hulu Kabupaten Kapuas Provinsi Kalimantan Barat [Tesis]. Yogyakarta: Program Pascasarjana, Universitas Gadjah Mada; 2011.

23. Adair LS, Guilkey DK. Age-specific determinants of stunting in Filipino children. J Nutr 1997;127(2):314-20.

24. Hizni A, Julia M, Gamayanti IL. Status stunted dan hubungannya dengan perkembangan anak balita di wilayah pesisir Pantai Utara kecamatan Lemahwunguk kota Cirebon. Jurnal Gizi Klinik Indonesia 2010;6(3):131-7.

25. Manary MJ, Salomons NW. Aspek kesehatan masyarakat pada gizi kurang. In: Gibney MJ, Margetts BM, Kearney JM, Arab L. Gizi kesehatan masyarakat. Jakarta: EGC; 2004. 